\title{
DCT wt Allele
}

National Cancer Institute

\section{Source}

National Cancer Institute. DCT wt Allele. NCI Thesaurus. Code C82886.

Human DCT wild-type allele is located in the vicinity of $13 q 32$ and is approximately $40 \mathrm{~kb}$ in length. This allele, which encodes L-dopachrome tautomerase protein, plays a role in the mediation of melanin biosynthesis. Aberrant expression of the gene is associated with melanoma. 